\title{
Tools to manage the decision-making process in operating rooms
}

\author{
Liliana Neriz', Daniela Silva ${ }^{1}$ Francisco Ramis², Alicia Núñez ${ }^{*}$ \\ From Health Services Research: Evidence-based practice \\ London, UK. 1-3 July 2014
}

\section{Background}

This study aims to build tools to manage and support decision making processes in operating rooms and related units. Activity-based costing $(A B C)$ was used in complement with performance measurement tools. The tools constructed were validated in five different hospitals in Chile; in this study we present the results from one of these hospitals.

\section{Methods}

We analyzed and created a model to deal with and better manage current problems in operating rooms such as inefficiency in the use of resources, low productivity, extended waiting times, and the elevated costs associated with providing surgical services. By gathering data from the surgical process, we built a dictionary of activities, identified the cost-drivers and the cost object to trace the overhead cost using the $\mathrm{ABC}$ methodology. In combination with the information obtained we identified indicators to measure performance associated to operating room use, using @risk software to simulate the optimum performance for continuous improvement.

\section{Results}

Based on the application of the data we found a disparity between the actual hospital costs and public health care insurance coverage suggesting a need to improve operating room efficiency to achieve sustainability. We also found gaps between the observed and ideal performance indicators and noted that time is a major factor.

\section{Conclusions}

The results of this study shows that implementing ABC and performance measurement tools lead to operational

'Department of Management Control and Information Systems, School of Economics and Business, Universidad de Chile, Santiago, Chile

Full list of author information is available at the end of the article improvements and better strategic decisions about rationalizing services, and improve hospital self-management.

\section{Authors' details}

'Department of Management Control and Information Systems, School of Economics and Business, Universidad de Chile, Santiago, Chile. ${ }^{2}$ Department of Industrial Engineering, Center of Advanced Studies in Process Simulation, Universidad del Bío-Bío, Concepción, Chile.

Published: 7 July 2014

doi:10.1186/1472-6963-14-S2-P86

Cite this article as: Neriz et al:: Tools to manage the decision-making process in operating rooms. BMC Health Services Research 2014 14(Suppl 2):P86.

Submit your next manuscript to BioMed Central and take full advantage of:

- Convenient online submission

- Thorough peer review

- No space constraints or color figure charges

- Immediate publication on acceptance

- Inclusion in PubMed, CAS, Scopus and Google Scholar

- Research which is freely available for redistribution

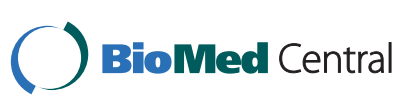

(C) 2014 Neriz et al; licensee BioMed Central Ltd. This is an Open Access article distributed under the terms of the Creative Commons Attribution License (http://creativecommons.org/licenses/by/4.0), which permits unrestricted use, distribution, and reproduction in any medium, provided the original work is properly cited. The Creative Commons Public Domain Dedication waiver (http:// creativecommons.org/publicdomain/zero/1.0/) applies to the data made available in this article, unless otherwise stated. 